\title{
The Moderating Influence of Financial Literacy on the Relationship of Financial Attitudes, Financial Self-Efficacy, and Credit Decision-Making Intensity
}

\author{
LD Gadi Djou ${ }^{*}$, Fitri Lukiastuti ${ }^{2 *}$ \\ ${ }^{1}$ Accounting Department, Flores University, Sam Ratulangi Street, Loa, Soa, Ende Regency, Nusa \\ Tenggara Timur. 86382, Indonesia \\ ${ }^{2}$ Magister Management, STIE Bank BPD Jateng, Soekarno Hatta Street no. 88, Semarang 50196, \\ Indonesia \\ *Corresponding author; Email: gadidjou@yahoo.com; fitrilukiastuti@gmail.com
}

\begin{abstract}
This study aims to determine the role of financial literacy moderation on the relationship between financial attitudes and financial self-efficacy on the intensity of decision-making of the SMEs that are also the customers of KUR BNI in Ende Regency amidst the COVID-19 pandemic situation. The objects of this research are all owners of large and retail trade SMEs, car and motorcycle repairs in Ende Regency (58 SMEs). The data analysis techniques used in this research is the Moderated Regression Analysis (MRA). The results are: (1) financial attitudes has positive influence on the credit decision-making intensity on SMEs, (2) financial self-efficacy has positive influence on the credit decision-making intensity of SMEs, (3) there is a moderation impact of financial literacy on the relationship between financial attitudes and credit decision making intensity for SMEs, and (4) financial literacy is able to moderate the relationship between self-efficacy and credit decision making intensity for SMEs.
\end{abstract}

Keywords: Financial literacy; financial attitudes; financial self-efficacy; credit decision making intensity; SMEs; people's business credit (KUR).

\section{INTRODUCTION}

Business activity is a very complex phenomenon because it covers various fields, including law, economics, and politics. The development of the national economy and the changes in the strategic environment facing the business world, including small and medium businesses, are currently swift and dynamic. In people's lives, human activity in the business world cannot be separated from the role of banks as providers of banking services to the community. The business world, especially the small and medium business sector, is one of the potentials that must be developed to encourage the achievement of national goals related to the improvement and equitable distribution of people's lives. This condition requires every entrepreneur, both small and medium-sized businesses, to make efforts to stabilize or further enhance their businesses' existence. One problem, which generally becomes a barrier, is the problem of capital for small and medium-sized businesses [18].

SMEs' ability to manage their business finances is crucial at this time. Every business looks at different aspects of its financial management, not only looking at short-term financial management matters, such as savings or loans, but also looking at the prospects of long-term financial management to expand its business. SMEs have an essential role in building the foundation of Indonesia's economy. During the several years of world economic crisis, Indonesian economy is in a stable condition because it benefits from the role of SMEs as resilient and flexible business sectors in facing economic dynamics [41]. Seeing the vital role of SMEs, the government seeks to provide capital stimulus to empower Small, Medium Enterprises, and Cooperatives. Efforts to increase access to funding sources which include, among others, providing credit guarantees to SMEs through the People's Business Credit (KUR). SMEs and cooperatives are expected to be able to access KUR engaged in productive business sectors include agriculture, fisheries, marine, industry, forestry, and savings and loan financial services [17].

People's Business Credit (KUR) is a credit loan launched by the government in assisting Micro, Small, and Medium Enterprises (SMEs) in obtaining additional funds to develop their businesses. Micro, Small, and Medium Enterprises that are entitled to get KUR assistance are SMEs that have productive businesses and deserve assistance. The intended productive business is a business in agriculture, fisheries and marine, industry, trade, and services (Appendix I of the Coordinating Ministerial Regulation for the Economy as Chair of 
the Financing Policy Committee for Micro and Medium Enterprises). Meanwhile, what is meant by SMEs must be eligible for the credit is a healthy MSME that can get profits so that it can repay loans that have been given.

There are three types of KUR: (1) micro KUR, with a maximum ceiling limit for each debtor of Rp. 25,000,000, (2) KUR retail, namely credit with a ceiling for each debtor above Rp. 25,000,000 and a maximum of Rp. 500,000,000, and (3) KUR TKI, which is a KUR loan to help finance the departure of Indonesian Migrant Workers (TKI) to the placement country with a maximum ceiling of Rp. $25,000,000$. This credit loan program without collateral is given to empower SMEs with an interest of nine percent per year as of 1 January 2016. This credit channeling is done through banking institutions and non-bank financial institutions which have been appointed and designated by the government because they are eligible as KUR fund channeling parties. Among them is PT Bank Nasional Indonesia (BNI). BNI's role in national development is undeniable, one of which is participating in the development and empowerment of Micro, Small, and Medium Enterprises (SMEs). BNI continues to actively support the Government's Program in developing SMEs through the provision of credit or financing to SMEs. The provision of credit or financing in the form of KUR to SMEs is one form of realizing economic independence that can drive strategic sectors of the domestic economy. Many small and medium scale national entrepreneurs developed into large entrepreneurs thanks to the contribution of BNI (www.bni.co.id, 5/02/2020).

PT Bank Negara Indonesia (Persero) Tbk states that the growth of lending this year will experience pressure due to the weakening economic conditions in Indonesia amid the COVID-19 pandemic (financial.bisnis.com/19/05/2020). Credit growth is predicted to end in the range of 2-4 percent annually. Likewise, with BNI in Ende District, there are several delays in installment payments which increase the value of NPLs. To overcome this situation, the strategy undertaken by BNI is to focus on improving asset quality and selectively channeling security across all segments, especially those affected by the COVID-19 pandemic. As of June 2020, 58 SMEs have received KUR assistance, with KUR uptake in the range of Rp 16 billion. SMEs that get a lot of KUR assistance are SMEs engaged in the production sector.

It takes effort, hard work, and high commitment from all entities of a bank so that the distribution of People's Business Credit (KUR) can run well. Education to prospective customers is needed because it is unfortunate if the bank loan products that have been designed by pro-SMEs are less clearly known; however, if they can be channeled, it will greatly help their capital needs [56].

The Financial Services Authority (OJK) encourages people to understand and comprehend financial literacy. It is because the Indonesian people's level of financial literacy is still far compared to financial inclusion. Based on the results of the National Literacy and Financial Inclusion Survey conducted by the OJK in 2019, the financial literacy index is recorded at 38.03 percent, while the financial inclusion index is 76.19 percent. It indicates that those who understood new financial products or financial services are few. Moreover, people have bought financial products but do not understand it. As if it has already entered but does not understand anything.

Because of that, OJK makes a joint commitment to financial services businesses to improve financial literacy, inclusion, and consumer protection. By doing so, it is expected that the level of financial inclusion will increase, and the consumer protection program will be implemented as targeted. Increasing financial inclusion and consumer protection is expected to bring economic growth in a positive direction. Financial inclusion is targeted to reach 75 percent in 2019 (ekbis.sindonews.com).

One factor that becomes an aspect of the SMEs' failure in accessing people's business credit funds is the SMEs' lack of understanding about what factors are essential assessments of banks in lending. Therefore, a study is needed on the effect of financial literacy, financial attitudes, and financial selfefficacy on credit decision-making for small and medium businesses of debtors in Ende.

The low level of financial literacy at SMEs has an impact on credit absorption by the banking sector. Four major obstacles must be faced by MSME actors, including limited working capital, human resources, product and technology innovation, and marketing. However, what is very common in capital problems is the cliché reason on why many SMEs do not develop: not all groups of people, especially low-income groups, can utilize financial products and services.

Based on the formulation of the Association of Chartered Certified Accountants (2014), financial literacy includes knowledge of financial concepts, understanding communication about financial concepts, the ability to manage personal or corporate finances, and the ability to make financial decisions in certain situations. Through good financial literacy, SMEs can utilize their financial knowledge in the decision-making process right for the business they are managing to achieve their goals and maintain business survival [60].

Referring to OJK data in 2014, the level of literacy among MSME actors is only 15.68 percent. 
The low level of financial literacy of business actors could cause various problems, including debt management, savings and credit management, and future planning. Significantly, higher financial literacy had a positive impact on the greater use of financial services [49]. [35], in their research, found that individuals who had good and diverse financial knowledge could increase their chances of success in gaining access to finance.

As [27] states, financial literacy will help business actors relate to business management, starting from the budget, planning to save business funds, and basic knowledge of finance to achieve business financial goals.

\section{Planned Behavior Theory (TPB)}

According to [28] and [58], TPB is an extension of the theory of reasoned action/TRA. In TRA, it is explained that one's intention towards behavior is formed by two main factors: attitude toward the behavior and subjective norms [30].

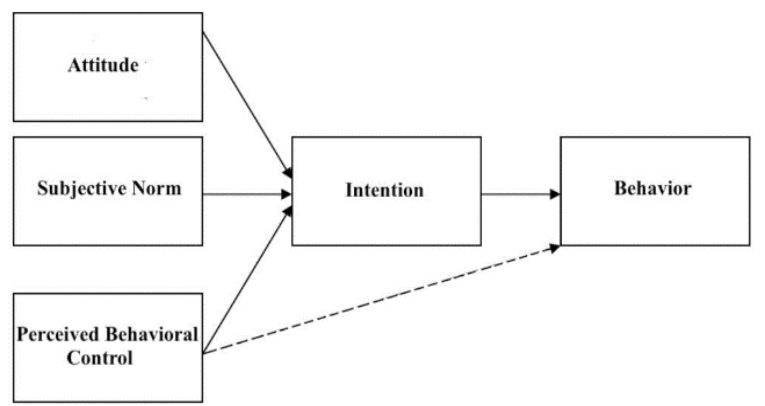

Figure 1. TPB (adopted from Ajzen, 1991).

According to [30], attitude is an individual's positive or negative evaluation of self-performance of a particular behavior. It is worthy of note that personal attitude towards a behavior can be negative or positive. Subjective norms are the factors that cause most people to believe that certain individuals expect special behavior from them. This implies that the belief of people in one's immediate environment, and the belief of family and friends, can affect a given individual's decision to perform a certain behavior.

Perceived behavioral control indicates that a person's motivation is influenced by how difficult the behaviors are perceived to be, as well as the perception of how successfully the individual can, or cannot, perform the activity. Perceived behavioral control has a direct effect on behavioral intention in the TPB model [21]. According to [14], the success of knowledge management depends on a considerable extent on people's intention to share knowledge because knowledge sharing requires people's intention to share their knowledge.
Meanwhile, in TPB, there is one more factor: perceived behavioral control [22]. TPB is very suitable to be used to explain various behaviors in entrepreneurship. As said by [3], TPB is suitable to explain any behavior that requires planning, such as entrepreneurship.

\section{Social Cognitive Theory}

According to [1] the social cognitive theory is developed by Albert Bandura in 1997 based on the statement that cognitive processes and social processes are vital in understanding human emotions, motivations, and actions. From a social cognitive perspective, individuals are more able to behave proactively and can regulate themselves rather than act controlled by external forces or outside environment. Besides, individuals also have the self-confidence that uses feelings, thoughts, and actions. [8] states that a person can develop selfperception about his ability to achieve goals and train what he wants to control his skills.

The social cognitive theory comes from the view of human agencies' existence. One crucial thing for agency people is self-efficacy formation. Self-efficacy not only knows what to do but also has the skills and confidence in their ability to perform. Belief in self-efficacy also determines how a person behaves [9]. Social cognitive theory is the basis for methods in explaining how perceptions of financial self-efficacy can influence financial management behavior.

\section{Financial Literacy}

According to [35] and [42], financial literacy is about knowledge or ability in managing personal finances and financial understanding of savings, insurance, and investment. [38] states that financial literacy is inseparable in one's life because it is a useful tool for making informed financial decisions. However, from the experiences of various countries, it still shows relatively low financial literacy.

[16] also found that low financial knowledge would lead to the making of wrong financial plans and could lead to the achievement of prosperity at unproductive age. According to the President's Advisory Council in Fornero and Monticone (2011) [24], financial literacy is the ability to use knowledge and skills to manage financial resources for a lifetime of well-being effectively.

\section{Financial Attitudes}

An understanding of financial attitudes will help individuals understand what is believed about their relationship with money. Individuals who are 
rational and more confident in the financial knowledge context will influence financial behavior far more profitably. Attitude refers to individuals' behavior who have personal financial problems which can be measured by responding to a statement or opinion [62]. Attitude is a picture of someone's personality that comes from physical movements and the mind's response to a situation or object. Meanwhile, a good attitude towards financial management starts with applying a good financial attitude. Without implementing a good attitude in finance, it is difficult to have a financial surplus for savings in the future, let alone investment capital [3].

\section{Financial Self-Efficacy}

The effect of financial self-efficacy on financial management behavior is based on social cognitive theory. In carrying out the job, a person must have the skills and confidence in the abilities possessed. Self-efficacy determines how a person behaves. According to [4], financial self-efficacy is a person's trust or belief in his ability to achieve his financial goals. When a person's level of trust is high, that person will be motivated to do everything to achieve his goals, also, when it is associated with someone's behavior in managing their finances. The higher the level of efficacy or level of trust of individuals, the better individuals or responsible in managing finances. High trust is caused by individual thinking related to financial management. In [40], financial self-efficacy is a variable that could also influence a person's saving behavior. Besides, financial self-efficacy could also affect a person's financial management behavior [19], [53]. This result is also reinforced by [52], who states that financial self-efficacy influenced behavior ]20].

\section{Hypothesis Development}

\section{The Influence of Financial Attitudes on the Credit Decisions Making Intensity by SMEs.}

Understanding financial attitudes will help someone to understand what is believed related to his relationship with. Therefore, the notion of financial attitude is defined as a state of mind, opinions, and judgments about finance. According to [54], the first aspect relates to the investor's confident personality in financial behavior, which is independent of the approach to his career, his health, and his finances. It is an emotional state, and how confident an investor is about certain things, or some investors tend to worry. The second element of the approach relates to whether investors think methodically, cautiously, and analytically in their financial behavior or emotional, intuitive, and patient.
Someone rational and more confident in terms of financial knowledge affects financial behavior that is more profitable. Research showed that a person generally does not have a great understanding of the financial knowledge level when financial knowledge is seen objectively and subjectively. These results indicated that some people believed that they had more knowledge of good and rational financial behavior than others [11]. The analysis supports the findings of [7], [13], and [46] who suggested that financial knowledge is objective, and financial beliefs or financial attitudes, which are subjective, produces a low level of correlation with financial behavior, and both have a significant impact on financial behavior. This study's results are supported by the theory of financial behavior perspectives, in which financial decision-makers neurologically tend to incorporate influences (emotions) into the decision-making process. The better a person's financial attitude or mentality, the better financial behavior in investment decisionmaking. It is the basis for formulating the first hypothesis as follows:

H1: Financial attitude has a positive influence on the credit decision-making intensity of SMEs.

\section{The Influence of Financial Self-Efficacy on the Credit Decision Making Intensity by SMEs.}

[20] describes financial self-efficacy as a set of psychological traits, including mental information or budgeting information overload, delays, regrets, and risk aversion. Self-efficacy is an individual's belief in his ability that he can do specific tasks. Many studies have been carried out on specific selfefficacy in this work domain [9], [15] and [25] have studied the relationship between self-efficacy and work-related performance. A study conducted by [23] and [43] on US people to analyze the psychology of male and female investment and assess the reasons why women making investments is quite conservative. They further work on human behavior in investing by evaluating the relationship between gender and investment risk together with the role of financial self-efficacy. This study reveals that compared to men, women make less risky investments and financial self-efficacy is positively related to the level of risk taken in the investment portfolio. Furthermore, gender differences affect investment and savings techniques, wealth accumulation, and portfolio choices [34]. Financial independence is not entirely affected based on financial literacy level or financial capacity alone. Conversely, elements such as personality, family background, interpersonal and social norms, and terms of reference also give rise to a person's financial independence [13], [31], [61]. 
Researchers have also studied the efficacy of individuals in the academic environment [51] and [63] have examined the relationship between selfefficacy perceptions and stress perceptions [12] and [45]. In a study of entrepreneurial self-efficacy, [35] and [47], argue that people who had high selfefficacy also tend to show more financial control. In a study conducted by [20] on women's financial selfefficacy, it is found that women who are confident in their ability to handle their finances also hold a diverse portfolio of financial products. In the planned behavior theory, it has been suggested that when individuals believe that behavior is within their control and they can exhibit certain behaviors, then perceive behavior control or self-efficacy can directly predict behavior [22]. From this explanation, the second hypothesis can be proposed, namely:

H2: Financial self-efficacy has a positive effect on SMEs' credit decision-making intensity in the short and long term.

The Moderating Influence of Financial Literacy on the Relationship of Financial Attitudes and Credit Decision Making Intensity by SMEs

The lack of financial literacy has made financial management ineffective. It will result in wrong consumer behavior [2]. The literature on financial literacy generally agrees that most consumers do not have the adequate financial literacy to make critical financial decisions in their best interest [37]. The risk of having some inherent negative feelings and the level of uncertainty that someone is willing to accept is always related to the possibility of bearing losses [33]. Financial attitude is more related to financial decision-making. People are careful when considering decisions of possible profit/loss, but when being put in a possible loss situation, they will take risky decisions, no matter how educated they are [44] and [55].

The results of research conducted by [5] and [46] reveal that there is a significant moderation effect of financial literacy on non-professional laypeople and provide insight to policymakers to work towards increasing literacy levels to optimize investment decisions. It can affect their attitude towards risky behavior.

H3: Financial Literacy moderates the relationship between Financial Attitudes and Credit Decisions Making Intensity by SMEs

The Moderating Influence of Financial Literacy on the Relationship of Financial SelfEfficacy and Credit Decision Making Intensity by SMEs

Financial self-efficacy comes from the initial self-efficacy that [9] and [39] built. He suggests that self-efficacy is best understood as "self-referent", which is thought to operate at the intersection between knowledge and action [9]. Determination of one's abilities and a very personal assessment of possible functions as a channel or roadblock to action. Those who believe they can manage their lives and environment, by definition, demonstrate self-efficacy behavior. In comparison, those who find themselves at the mercy of their condition show themselves to be ineffective. Effective assessments of individual circumstances tend to encourage behaviors (actions) in positive and productive ways that lead to greater potential for personal success and overall well-being. Conversely, individual-level vigilance results in increased stress and disturbances at times of perceived challenges. The presence of self-efficacy ensures that a person engages in a behavior (seeking help and advocating themselves among themselves), which enhances their ability to handle diverse and complex situations. Self-efficacy is a must. Therefore, it is understood to be a complex process in which "cognitive, social, and behavioral skills components must be organized into integrated actions" [9] (p. 122). A high level of perceived self-efficacy reflects self-confidence, and the individual has shown the capacity for success [9] and [39]. Based on these explanations, the following hypotheses is proposed:

H4: Financial Literacy moderates the relationship between Financial Self-Efficacy and Credit Decision Making Intensity by SMEs.

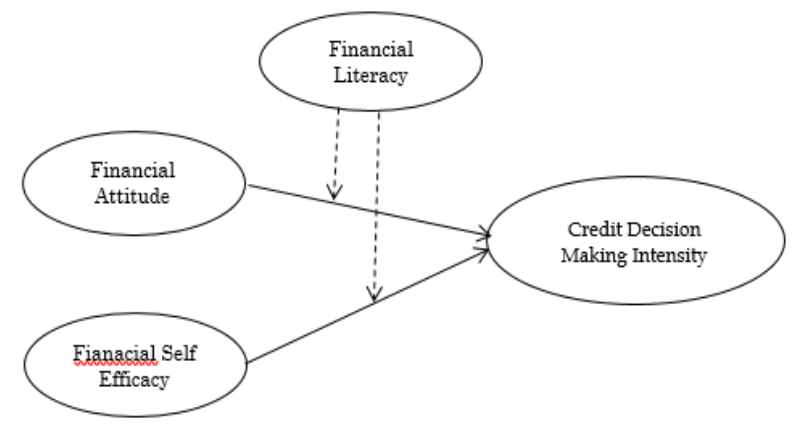

Figure 2. Research Method

\section{RESEARCH METHOD}

The population involved in this study are the owners of large and retail trade Micro, Small, and Medium Enterprises (SMEs), car and motorcycle repairs that are KUR BNI customers in Ende Regency. This study's total population is 220 SMEs, both those who are formal credit debtors and those who are not. The sample taken using the Slovin formula is $98 \approx 100$ SMEs.

The sampling technique used is random sampling with the respondents' criteria: SMEs classified as customers of Bank BNI Ende Branch. Research 
data employ primary data with data collection methods utilizing the questionnaire distribution media. The questions in the questionnaire use an interval scale in the form of a Likert scale that produces answers from strongly agree to strongly disagree, with the value range of 1-5 [57].

\section{Measurement}

Financial Attitude (X1). Financial attitude is defined as a condition that gives rise to a view or opinion as well as an assessment of an individual's finances, which is then applied to an attitude. Financial attitude is also defined as applying several principles that exist in financial concepts to create and maintain value for money through appropriate decision making and management [50]. Good financial attitude can be measured by the five components of one's ability to show patterns good thinking about money (obsession), able to control one financial situation owned (effort), adjust the use of money towards necessity (inadequacy), don't want to spend money (retention), and has a broad view against money (securities) [29].

Financial self-efficacy (X2). According to [26] dan [48], financial self-efficacy is a person's belief or trust in his ability to achieve his financial goals and is influenced by several factors, including financial skills, personality, social, and other factors. Indicators used to measure financial self-efficacy variables based on [39] include the ability to plan financial expenditures, the ability to achieve financial goals, the ability to make decisions when unexpected events arise, the ability to face financial challenges, confidence in financial management, and confidence in the financial condition in the future.

Financial Literacy (X3). Financial literacy is a series of processes or activities to increase the knowledge, skills, and confidence of consumers and the broader community so that they can manage personal finances better (Financial Services Authority, 2016). Financial literacy indicators include knowledge of basic financial management, knowledge of financial budgeting, knowledge of interest rates and credit, having the ability to compare the benefits of offers offered by financial services, and being able to communicate about financial concepts [32].

Credit Decision Making Intensity (Y). According to Schiffman (in [36]), the intensity of customer decisions in taking credit is the choice of two or more choices for making credit, meaning that someone can decide that there must be other alternatives available. The indicators of the intensity of customer decisions in taking credit are the interest rate, availability of information, the process of lending, the distance between the house to the Bank/Location of the Bank, the amount of credit, and employee service consideration [59].

The analytical methods used are qualitative and quantitative analysis methods. Qualitative analysis methods are employed to describe the research object, such as the condition of the research place, the characteristics of the subjects studied, the conditions of the selected respondents, and the relationship between variables to conclude the quantitative analysis conducted. The quantitative analysis method is utilized to show the significance of each independent variable examined based on the moderating regression analysis tool (MRA), which will be processed through SPSS software.

\section{RESULTS AND DISCUSSION}

\section{Overview of Credit in Ende Regency}

Credit in Ende Regency is divided into several forms. Based on the form of the credit institution that provides it, there are formal and informal loans available to SMEs in Ende Regency. Loans from formal institutions consist of conventional credit, KUR, non-bank financing institutions, and cooperatives. BNI credit products are divided into two, distinguished by the number of credit ceilings and loan interest rates. BNI KUR is a form of government-subsidized credit, and the interest rate charged is lower than ordinary credit, less than 10 percent per year. Even so, BNI KUR is still rarely taken by UKM because of the limited quota for BNI KUR. Both BNI KUR and conventional BNI credit require collateral, such as a motorbike's BPKB, Land Purchase Deed, and other asset ownership certificates.

To access credit from banks, many SMEs are helped by the role of mediators who assist them take care of the conditions needed to get a loan. The mediator can help complete the documents needed by farmers and recommend farmers to the bank. The bank also sees the mediator as an informal guarantor who will be morally responsible for bad credit. As a result, the mediator will also have a role to remind customers whose debts are experiencing congestion. In Ende District, most SMEs that took credit from banks are successfully accepted by their loans thanks to mediators' help.

Another formal credit institution widely used by farmers is the savings and loan cooperatives (19 units) (Ende in figures, page 399, BPS, 2018). There are three units in Nangapanda Subdistrict, two units in Ende Subdistrict, one unit in South Ende Subdistrict, one unit in East Ende Subdistrict, 11 units in Central Ende Subdistrict, and one unit in Ndori District. 
The last formal credit is consumption credit. The institutions chosen by respondents in this study are Adira Credit and FIF. Based on the research, this credit is used for various expenses such as medical expenses, purchase of motor vehicles, and home renovations. To get this credit, the debtor must prepare his/her ID Card, Family Card, and collateral in the form of a motorbike's BPKB or land/house certificate. Informal Credit refers to a financing institution that does not have a legal entity.

Informal credit is usually provided with greater capital trust and interest. Based on research, the informal credit found here tend not to have a fixed pattern and is few in number. This loan is usually given by individuals who work as farmers with large tracts of land. Based on the interviews conducted with farmers, this informal credit is usually used to pay for household needs when the price of vegetable commodities falls, or when crop failures occur due to bad weather.

\section{Demographics of Respondents}

Table 1. Characteristics of Respondents by Gender.

\begin{tabular}{clcc}
\hline No & Gender & Amount & \% \\
\hline 1 & Male & 40 & $68,97 \%$ \\
2 & Female & 18 & $31,03 \%$ \\
\hline & Total & 58 & $100 \%$ \\
\hline
\end{tabular}

Source: processed primary data, 2020.

Respondents in this study showed that from a total of 58 questionnaires that gave answers, it is dominated by respondents with male gender that is equal to 68.97 percent or 40 respondents. Meanwhile, female respondents are only 31.03 percent or 18 respondents from 58 respondents. It is consistent with the facts obtained that the SME owners/managers in Ende Regency are dominated by male.

Table 2. Characteristics of Respondents by Age

\begin{tabular}{|c|c|c|c|}
\hline No & Age & Amount & $\%$ \\
\hline 1 & $\leq 30$ & 15 & $17 \%$ \\
\hline 2 & $30-50$ & 34 & $58 \%$ \\
\hline 3 & $\geq 50$ & 9 & $25 \%$ \\
\hline \multicolumn{2}{|c|}{ Total } & 58 & $100 \%$ \\
\hline
\end{tabular}

Source: processed primary data, 2020.

Respondents in this study are also dominated by those under the age of 50 years. The age group is thought to have a positive effect on credit taking. This productive age of MSME owners/managers has gained a lot of business experience, which ultimately make their businesses more likely to get the credit. Age over 50 years is also a consideration of formal credit institutions to provide credit, which is related to business productivity guarantees that will have an impact on the payment process of KUR loan installments. BNI must be more careful in extending KUR loans, especially during the COVID-19 pandemic.

Table 3. Characteristics of Respondents by Family Dependents

\begin{tabular}{cccc}
\hline No & Family Dependents & Amount & \% \\
\hline 1 & $<2$ & 5 & $8 \%$ \\
2 & $3-5$ & 45 & $78 \%$ \\
3 & $>5$ & 8 & $14 \%$ \\
\hline & Total & 58 & $100 \%$ \\
\hline
\end{tabular}

Source: processed primary data, 2020.

The respondents in this study is dominated by respondents with family dependents of three to five with a total of 45 respondents. While respondents with family dependents more than five people amounted to eight respondents, and respondents with family dependents of less than two people amounted to five respondents from 58 respondents. It indicates that the number of family dependents has a negative effect on formal credit taking. More family dependents will increasingly encourage the need to increase income because of greater household needs. These increasingly high needs make it more difficult for respondents to access credit because of the higher percentage of income allocated to household needs. This less income makes the risk of taking credit became greater. The average of the total family dependents of all respondents is 3-4 people.

Table 4. Characteristics of Respondents based on Education Level

\begin{tabular}{clcc}
\hline No & Education Level & Amount & \% \\
\hline 1 & Elementary School & 10 & $18 \%$ \\
2 & Junior High School & 13 & $23 \%$ \\
3 & Senior High School & 15 & $31 \%$ \\
4 & Graduate Level & 20 & $28 \%$ \\
\hline & Total & 58 & $100 \%$ \\
\hline
\end{tabular}

Source: processed primary data, 2020.

Education level is thought to have a positive effect on formal credit withdrawal. It is assumed that the higher the level of education of the respondents, the more easily exposed they will to information related to formal credit. The respondents will also find it easier to use information about formal credit if they have a higher literacy rate.

Table 5. Characteristics of Respondents Based on Length of Business.

\begin{tabular}{cccc}
\hline No & Family Dependents & Amount & $\mathbf{\%}$ \\
\hline 1 & $1-3$ years & 9 & $15 \%$ \\
2 & $4-7$ years & 17 & $30 \%$ \\
3 & $>8$ years & 32 & $55 \%$ \\
\hline \multicolumn{2}{c}{ Total } & 58 & $100 \%$ \\
\hline
\end{tabular}

Source: processed primary data, 2020. 
This means that the length of business has a positive effect on formal credit withdrawal. The longer a business is, the more experience you can get to optimize production, and the more knowledge you will get to meet market needs. Length of business also indicates a respondent's ability to create resilience for their business against the changing markets and externalities. In addition, the length of the business may also imply that the business will be more likely to expand to the point where additional venture capital will become required. These are very influential in creating a business that is deemed worthy of obtaining and taking credit.

\section{Descriptive Statistics}

\section{Financial Attitude}

Table 6. Summary of Respondents' Answers on Financial Attitude Variables

\begin{tabular}{lcccccc}
\hline Items & (5) & $\mathbf{( 4 )}$ & $\mathbf{( 3 )}$ & $\mathbf{( 2 )}$ & $\mathbf{( 1 )}$ & Average \\
\hline X1.1 & 3 & 18 & 20 & 15 & 2 & 3,24 \\
X1.2 & 2 & 19 & 15 & 18 & 4 & 2,94 \\
X1.3 & 5 & 22 & 14 & 14 & 3 & 3,20 \\
X1.4 & 3 & 18 & 20 & 15 & 2 & 3,08 \\
X1.5 & 4 & 22 & 12 & 19 & 1 & 3,16 \\
\hline \multicolumn{7}{c}{ Total Average } \\
\hline
\end{tabular}

Source: processed data, 2020.

The summary of respondents' answers on the financial attitude variable shows the total average value of 3.12. This indicates that the average respondent's answers are still in a position of quite agree or somewhat agree and some even don't agree with their financial attitude. Especially for the response to the second indicator question regarding the adjustment of the use of money towards necessity (inadequacy). However, the response to the first indicator regarding show patterns good thinking about money (obsession) still shows the highest response.

\section{Financial Self Efficacy}

Table 7. Summary of Respondents' Answers on Financial Self Efficacy Variables

\begin{tabular}{lcccccc}
\hline Items & (5) & (4) & (3) & (2) & (1) & Average \\
\hline X2.1 & 29 & 17 & 9 & 4 & - & 4,19 \\
X2.2 & 25 & 25 & 7 & 1 & - & 4,28 \\
X2.3 & 24 & 23 & 10 & 1 & - & 4,21 \\
X2.4 & 30 & 25 & 3 & - & - & 4,47 \\
X2.5 & 27 & 24 & 5 & 2 & - & 4,31 \\
X2.6 & 30 & 21 & 5 & 2 & - & 4,36 \\
\hline \multicolumn{7}{c}{ Total Average } \\
\hline
\end{tabular}

Source: processed data, 2020.
The summary of respondents' answers on the financial self-efficacy variable shows the total average value of 4,30 . This indicates that the average respondent's answers are 'agree' and 'strongly agree', there are even some respondents that answer 'quite agree' and 'somewhat agree' with their financial self-efficacy. Especially for the response to the fourth indicator question regarding the ability to face financial challenges still shows the highest response. However, the response to the first indicator regarding the ability to plan financial expenditures still shows the lowest response.

\section{Financial Literacy}

Table 8. Summary of Respondents' Answers on Financial Literacy Variables

\begin{tabular}{lcccccc}
\hline Items & $\mathbf{( 5 )}$ & $\mathbf{( 4 )}$ & $\mathbf{( 3 )}$ & $\mathbf{( 2 )}$ & $\mathbf{( 1 )}$ & Average \\
\hline X3.1 & 4 & 16 & 17 & 14 & 7 & 2,93 \\
X3.2 & 4 & 19 & 15 & 17 & 3 & 3,07 \\
X3.3 & 5 & 17 & 12 & 18 & 6 & 2,95 \\
X3.4 & 4 & 14 & 22 & 13 & 5 & 2,98 \\
X3.5 & 1 & 18 & 17 & 19 & 3 & 2,91 \\
X3.6 & 5 & 16 & 18 & 17 & 2 & 3,09 \\
\hline \multicolumn{7}{c}{ Total Average } \\
\hline
\end{tabular}

Source: processed data, 2020.

The summary of respondents' answers on the financial literacy variable shows the total average value of 2,98. This indicates that the average respondent's answers are still in a position of agree, quite agree, and some even somewhat agree and don't agree with their financial literacy. Especially for the response to the sixth indicator question regarding the ability to face financial challenges still shows the highest response. However, the response to the first indicator regarding the ability to plan financial expenditures still shows the lowest response.

\section{Credit Decision Making Intensity}

Table 9. Summary of Respondents' Answers on Credit Decision Making Intensity

\begin{tabular}{lllllll}
\hline Items & (5) & (4) & (3) & (2) & (1) & Average \\
\hline Y.1 & 41 & 14 & 2 & 1 & - & 4,64 \\
Y.2 & 39 & 14 & 5 & - & - & 4,59 \\
Y.3 & 30 & 24 & 4 & - & - & 4,45 \\
Y.4 & 31 & 25 & 2 & - & - & 4,50 \\
Y.5 & 36 & 16 & 2 & 3 & 1 & 4,43 \\
Y.6 & 36 & 21 & 1 & - & - & 4,60 \\
\hline \multicolumn{7}{c}{ Total Average } \\
\hline
\end{tabular}

Source: processed data, 2020.

The summary of respondents' answers on the credit decision-making intensity shows the total average value of 4,60 . This indicates that the 
average respondent's answers are still in a position of strongly agree and agree with their decisionmaking intensity to take credit. Especially for the response to the first indicator question regarding the interest rate of credit still shows the highest response, and next in the second order is the sixth indicator regarding employee service consideration.

\section{Moderated Regression Analysis}

Based on Figure 2, the mathematical model of the relationship between variables is as follows:

$\mathrm{Y}=\mathrm{a} 1+\mathrm{b} 1 \mathrm{X} 1+\mathrm{b} 3 \mathrm{X} 3+\mathrm{b} 5 \mathrm{X} 1 \mathrm{X} 3+\mathrm{e} 1$

$\mathrm{Y}=\mathrm{a} 2+\mathrm{b} 2 \mathrm{X} 2+\mathrm{b} 4 \mathrm{X} 3+\mathrm{b} 6 \mathrm{X} 2 \mathrm{X} 3+\mathrm{e} 2$

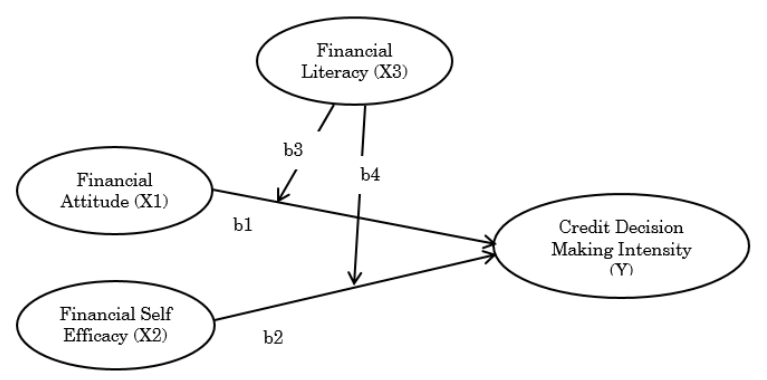

Table 10. Summary of Equation Results 1

\begin{tabular}{|c|c|c|c|c|c|c|}
\hline \multicolumn{7}{|c|}{ Coefficients a } \\
\hline & \multirow{2}{*}{ Model } & \multicolumn{2}{|c|}{$\begin{array}{l}\text { Unstand. } \\
\text { Coeff. }\end{array}$} & \multirow{2}{*}{$\begin{array}{c}\begin{array}{c}\text { Stand. } \\
\text { Coeff. }\end{array} \\
\text { Beta }\end{array}$} & \multirow[b]{2}{*}{$\mathbf{t}$} & \multirow{2}{*}{ Sig. } \\
\hline & & B & $\begin{array}{c}\text { Std. } \\
\text { Error }\end{array}$ & & & \\
\hline \multirow[t]{4}{*}{1} & (Constant) & -.725 & 7.572 & & -.096 & .924 \\
\hline & F. Att (X1) & 1.247 & .478 & 1.546 & 2.609 & .012 \\
\hline & F. Lit (X3) & 1.358 & .430 & 1.763 & 3.157 & .003 \\
\hline & Moderate1 & -.057 & .027 & -2.003 & -2.137 & .037 \\
\hline & Dependent & able: I & ensity (Y) & & & \\
\hline
\end{tabular}

$\mathrm{R}^{2}=0.586$, Adj. $\mathrm{R}^{2}=0.563, \mathrm{~F}$ Test $=25.520$ Probability $=0.000$

Source: processed primary data, 2020.

Analysis:

\section{Coefficient of Determination}

The value of Adjusted R Square (R2) is 0.586, meaning that 58.6 percent of $\mathrm{Y}$ variation can be explained by the independent variables $\mathrm{X} 1, \mathrm{X} 3$, and moderate1. While the rest (41.4 percent) are explained by other causes beyond the model.

\section{The Goodness of Fit (F Test)}

The $\mathrm{F}$ test yields a calculated $\mathrm{F}$ value of 25.5207 with a level significance of 0.000 . Because the probability of significance is much smaller than 0.05 , the regression model can be used to predict $\mathrm{Y}$ or it can be said that X1, X3, and moderate 1 together influence $\mathrm{Y}$.

\section{$t$-Test}

The variable $\mathrm{X} 1$ provides a coefficient value parameter of 1.247 with a level significance of 0.000 $(<0.05)$. Variable X3 provides the parameter coefficient value amounted to 1.358 with a significance level of $0.000(<0.05)$. Moderate variable 1 provides the parameter coefficient value of $-0,057$ with a significance level equal to $0.000(<0.05)$. Moderate variable 1 , which is the interaction between X1 and X3, turns out to be significant, so it can be concluded that the variable $\mathrm{X} 3$ is moderating variable.

Table 11. Summary of Equation Results 2

\begin{tabular}{|c|c|c|c|c|c|c|}
\hline \multicolumn{7}{|c|}{ Coefficients a } \\
\hline & \multirow{2}{*}{ Model } & \multicolumn{3}{|c|}{ Unstand. Coeffi. $\begin{array}{l}\text { Stand. } \\
\text { Coeff. }\end{array}$} & \multirow{2}{*}{$\mathbf{t}$} & \multirow{2}{*}{ Sig. } \\
\hline & & B & $\begin{array}{l}\text { Std. } \\
\text { Error }\end{array}$ & Beta & & \\
\hline \multirow[t]{4}{*}{$\overline{1}$} & (Constant) & -9.910 & 7.097 & & -1.396 & .168 \\
\hline & F. Eff (X2) & 1.257 & .289 & 1.359 & 4.357 & .000 \\
\hline & F. Lit (X3) & 1.405 & .410 & 1.823 & 3.427 & .001 \\
\hline & Moderate2 & -.044 & .016 & -2.039 & -2.750 & .008 \\
\hline
\end{tabular}

a. Dependent Variable: Intensity (Y)

$\mathrm{R}^{2}=0.709$, Adj. $\mathrm{R}^{2}=0.693, \mathrm{~F}$ Test $=43.920$ Probability $=0.000$

Source: primary data is processed, 2020

Analysis:

\section{Coefficient of Determination}

The value of Adjusted R Square (R2) is 0.709, meaning that 70.9 percent of $\mathrm{Y}$ variation can be explained by the independent variables X2, X3, and moderate2. While the rest (29.1 percent) are explained by other causes beyond the model.

\section{The Goodness of Fit (F Test)}

The F test yields a calculated $\mathrm{F}$ value of 43.920 with a level significance of 0.000 . Because the probability of significance is much smaller than 0.05, the regression model can be used to predict Y or it can be said that X2, X3, and moderate 2 together influence Y.

\section{$t$-Test}

The variable X2 provides a coefficient value parameter of 1.257 with a level significance of 0.000 $(<0.05)$. Variable X3 provides the parameter coefficient value amounted to 1.405 with a significance level of $0.000(<0.05)$. Moderate variable 2 provides the parameter coefficient value of $-0,044$ with a significance level equal to $0.000(<0.05)$. Moderate variable 2 which is the interaction between X2 and X3 turns out to be significant, so it can be concluded that the variable X3 is moderating variable.

\section{The Influence of Financial Attitudes towards Credit Decision Making Intensity by SMEs}

Table 10 shows that the financial attitude variable had a positive and significant influence on the intensity of SME credit taking on SME 
owners/managers in the Ende Regency. The financial attitude variable is an understanding that helps individuals to be rational and further increases their confidence in terms of their understanding of money. It will be seen with the responses issued in the form of statements or opinions about money. The results of this study are in line with research conducted by [6], [7], and [46], especially aspects relating to the investor's confident personality in financial behavior, it is independent of the approach to his career, his health, and his finances. The security of higher financial conditions leads to confidence and increases the desire for self-development of financial conditions. It is positive with the perspective of financial behavior perspectives that financial decision-making neurologically tends to incorporate the influence of emotions into the decision-making process.

\section{The Influence of Financial Self-Efficacy on Credit Decision Making Intensity by SMEs}

Based on table 11, the financial self-efficacy variable has a positive and significant effect on the intensity of SME credit decision-making and its influence is quite large, so it can be interpreted that investment decisions must be made based on capital confidence in one's abilities and actual abilities and other supporting factors are needed. This result is in accordance with [35] and [47], who state that financial self-efficacy has a significant positive effect on one's financial satisfaction. Likewise, with research [20] on women's financial self-efficacy, it is found that women who are confident in their ability to handle their finances also hold a diverse portfolio of financial products. However, in Ende Regency, most of the KUR customers are men. Women do not have a dominant role in decision-making. Coupled with the existence of a culture of authority in Ende, it requires men to be the primary decision-makers. In the COVID-19 pandemic situation, as it is today, there is a great demand for self-confidence, innovation, and creativity in making a portfolio of their business assets.

\section{Moderating Influence of Financial Literacy on the Relationship of Financial Attitudes and Credit Decision Making Intensity by SMEs}

Table 10 shows that financial literacy could significantly moderate the relationship between financial attitudes and credit decision-making intensity by -0.057 . This result is in line with the research of [5] and [46], which shows a significant moderation effect of financial literacy on the public. This study's findings indicate that respondents are included in the category of risk-averse, even though the results indicate that the decision is moderated by financial literacy. They tend to diversify to avoid loan risk. It means that respondents still have the responsibility to make loan payments even though the business situation is tough during this pandemic. The BNI bank must set lighter loan requirements.

\section{Moderating Influence of Financial Literacy on the Relationship of Financial Self-Efficacy and Credit Decision Making Intensity by SMEs.}

Table 11 shows that financial literacy could significantly moderate the relationship between financial self-efficacy and credit decision-making intensity by -0.044 . These results are in line with research by [10]. It is due to the COVID-19 pandemic situation, which results in a decrease in their business so that their confidence also decreases. In this situation, they must continue to rise to solve various kinds of problems they face.

The self-confidence of the entrepreneurs themselves is determined by one personality that is low neuroticism. Neuroticism is an individual personality that describes the nature of often feeling depressed, full of tension and worries, easily moody and sad, and easily agitated. Individuals with this personality are said to have unstable emotions. It means that the self-confidence of SMEs entrepreneurs will be difficult to emerge if the individual still has not stabilized his emotions.

\section{CONCLUSIONS}

Financial attitude has a significant influence on credit decision-making intensity by SMEs entrepreneurs in Ende Regency. It shows that the financial decision-making of SMEs owners/managers tends to incorporate influence (emotions) into the decision-making process.

The financial self-efficacy variable significantly influences SMEs' credit decision-making intensity for entrepreneurs in Ende Regency. Financial selfefficacy is a person's belief in his ability to do something or work that is his responsibility. Someone with high financial self-efficacy will feel capable and optimistic about completing his work and responsibilities. Conversely, people with low financial selfefficacy will feel that they are unable and pessimistic to complete their work and responsibilities. Entrepreneurs with high financial self-efficacy have confidence that they can solve business problems, follow their business processes well, and feel capable of carrying out their responsibilities as entrepreneurs.

Financial literacy can significantly moderate the relationship between financial attitudes and the intensity of SMEs credit decision-making 
entrepreneurs in Ende Regency, although its role is not significant. The concentration is currently on the recovery of their business.

Financial literacy can moderate significantly the relationship of financial self-efficacy and the intensity of SMEs credit decision-making entrepreneurs in Ende Regency. The biggest concentration is on their efforts to be able to repay KUR loans.

\section{Suggestions and Managerial Implication}

In the financial attitude, there needs to be an increase in self-development. It is because, in positive financial behavior, it is necessary to develop posts that are invested. Self-development in financial matters can be done by investing in more than one type (long term, emergency savings, and short term), saving regularly every month, paying all bills timely, avoiding debt, housing planning, insurance, and others.

In accordance with the results of research and discussion, BNI is advised to pay more attention to self-efficacy because it has been proven to affect SME entrepreneurs' in-role performance. Especially regarding their ability to control their emotions in dealing with problems, the BNI bank should increase their attention by providing training programs on increasing their self-confidence so that they can help SMEs to develop themselves, control their emotions, and enhance their abilities. This training can be given on an ongoing basis.

Decision-makers need to protect risk factors through innovation in financial products. Because this research has limitations in stratifying the sample to cover all segments of the community and the adapted questions are difficult to understand, future research can target the segment of society planned for stratification for the same representative. Besides, this study does not analyze crosscountry results comparisons, which can be used to improve the results of this study.

SMEs entrepreneurs in Ende Regency must pay more attention to financial self-efficacy factors, especially in completing work on time, being creative in all activities, and motivating themselves effectively to increase the ability of entrepreneurs to complete their obligations.

Financial literacy can moderate the relationship between financial attitudes and financial efficacy on the intensity of credit decision making, but the results of this moderation have a negative value, meaning that financial literacy weakens the relationship between financial attitudes, financial efficacy on the intensity of credit decision making even though the percentage is not large. This is because most of the respondents' education level is still low (see table 4). As we know, financial literacy is closely related to individual welfare. Financial knowledge and skills in managing personal finances are very important in everyday life, especially in the current Covid-19 pandemic situation. Financial difficulties are not only a function of income alone (low income). Financial difficulties can also arise if there are errors in financial management (mismanagement) such as misuse of credit and absence of financial planning. Financial limitations can cause stress and low self-esteem. The existence of financial knowledge and financial literacy will help individuals in managing personal financial planning so that the individual can maximizing the time value of money and the benefits obtained by individuals will be even greater and will increase the standard of living.

\section{REFERENCES}

[1] Abdullah, S. M. (2019). Social Cognitive Theory: A Bandura Thought Review published in 1982-2012. Psikodimensia, 18(1), 85. https://doi. org/10.24167/psidim .v18i1.1708

[2] Adam, A. M., Frimpong, S., \& Boadu, M. O. (2017). literacy and financial planning: Implication for financial well-being of retirees. Business and Economic Horizons, 13(2), 224236. https://doi.org/10.15208/ beh.2017.17

[3] Ajzen, I. (2011). The theory of planned behaviour: Reactions and reflections. Psychology and Health, 26(9), 1113-1127. https://doi. org/10.1080/08870446. 2011.613995

[4] Amran, N. A. (2011). the Effect of Owner's Gender and Age To Firm Performance: a Review. Journal of Global Business and Economics, 2(1), 104-116.

[5] Aren, S., \& Dinç Aydemir, S. (2015). The Moderation of Financial Literacy on the Relationship Between Individual Factors and Risky Investment Intention. International Business Research, 8(6). https://doi.org/10.5539/ ibr.v8n6p17

[6] Arianti, B. F. (2017). The Influence of Financial Literacy, Financial Behavior and Income on Investment Decision. European Research Studies Journal, 20(3A), 635-648.Arianti, B. F. (2017). The Influence of Financial Literacy, Financial Behavior and Income on Investment Decision. European Research Studies Journal, 20(3A), 635-648.

[7] Arifin, A. Z. (2017). The influence of financial knowledge, control and income on individual financial behavior. European Research Studies Journal, 20(3), 635-648.

[8] Bandura,Albert. (1999). Social Cognitive Theory: An Agentic Perspective. Asian Journal of Social Psychology, 2(1), 1-26. http://search. 
ebscohost.com/login.aspx?direct=true\&\#38; $\mathrm{db}=\mathrm{aph} \& \% 2338 ; \mathrm{AN}=4369846 \& \% 2338 ;$ site $=\mathrm{e}$ host-live

[9] Bandura, A. (1982). Self-efficacy mechanism in human agency. American Psychologist, 37(2), 122-147. https://doi.org/10.1037/0003-066X.37. 2.122

[10] Bandura, A. (2006). Toward a Psychology of Human Agency. Perspectives on Psychological Science, 1(2), 164-180. https://doi.org/10.1111/ j.1745-6916.2006.000 11x

[11] Bouteska, A., \& Regaieg, B. (2020). Loss aversion, overconfidence of investors and their impact on market performance evidence from the US stock markets. Journal of Economics, Finance and Administrative Science, 25(50), 451-478. https:// doi.org/10.1108/JEFAS-072017-0081

[12] Burger, K., \& Samuel, R. (2017). The Role of Perceived Stress and Self-Efficacy in Young People's Life Satisfaction: A Longitudinal Study. Journal of Youth and Adolescence, 46(1), 78-90. https://doi.org/10.1007 /s10964-0160608-x

[13] Butterbaugh, S. M., Ross, D. B., \& Campbell, A. (2020). My Money and Me: Attaining Financial Independence in Emerging Adulthood Through a Conceptual Model of Identity Capital Theory. Contemporary Family Therapy, 42(1), 33-45. https://doi.org/10.1007/ s10591019-09515-8

[14] Chatzoglou, P. D., \& Vraimaki, E. (2009). Knowledge-sharing behaviour of bank employees in Greece. Business Process Management Journal, 15(2), 245-266. https://doi.org/10. 1108/14637150910949470

[15] Damanik, Y. R., Lumbanraja, P., \& Sinulingga, S. (2020). The Effect of Talent Management and Self-Efficacy through Motivation toward Performance of Population and Civil Notice of Simalungun District. International Journal of Research and Review (Ijrrjournal.Com), 7(1), 1.

[16] Dewi, V. I., Febrian, E., Effendi, N., \& Anwar, M. (2020). Financial literacy among the millennial generation: Relationships between knowledge, skills, attitude, and behavior. Australasian Accounting, Business and Finance Journal, 14(4), 24-37. https://doi.org/10.14453/ aabfj.v14i4.3

[17] Efriyenty, D., \& Janrosl, S. E. (2017). Dian Efriyenty dan Viola Syukrina E Janrosl Dosen Universitas Putera Batam (Naskah diterima: 22 April 2017, disetujui: 22 Mei 2017). 1.

[18] Etemad, H. (2020). Managing uncertain consequences of a global crisis: SMEs encountering adversities, losses, and new opportunities. Journal of International Entrepreneurship,
18(2), 125-144. https://doi.org/10.1007/s10843020-00279-z

[19] Fanani, Z., \& Saudale, G. E. K. (2019). Influence of Information Asymmetry and SelfEfficacy on Budgetary Slack: An Experimental Study. Jurnal Akuntansi Dan Keuangan, 20(2), 62. https://doi.org/10.9744/jak.20.2.62-72

[20] Farrell, L., Fry, T. R. L., \& Risse, L. (2016). The significance of financial self-efficacy in explaining women's personal finance behaviour. Journal of Economic Psychology, 54, 85-99. https://doi.org/10. 1016/j.joep.2015.07.001

[21] Fishbein, M. (2021). The Influence of Attitudes on Behavior. The Handbook of Attitudes, January 2005, 187-236. https://doi.org/10. 4324/9781410612823-13

[22] Fishbein, M., \& Ajzen, I. (2005). The Influence of Attitudes on Behavior. The Handbook of Attitudes, July, 173-222.

[23] Fisher, P. J., \& Yao, R. (2017). Gender differences in financial risk tolerance. Journal of Economic Psychology, 61(March), 191-202. https://doi.org/10. 1016/j.joep.2017.03.006

[24] Fornero, E., \& Monticone, C. (2011). Financial literacy and pension plan participation in Italy. Journal of Pension Economics and Finance, 10(4), 547-564. https://doi.org/10.1017/S1474 747211000473

[25] Foulstone, A. R., \& Kelly, A. (2019). Enhancing academic self-efficacy and performance among fourth year psychology students: Findings from a short educational intervention. International Journal for the Scholarship of Teaching and Learning, 13(2). https://doi.org/ 10.20429/ijsotl.2019.130209

[26] Ghosh, S., \& Vinod, D. (2017). What Constrains Financial Inclusion for Women? Evidence from Indian Micro data. World Development, 92, 60-81. https://doi.org/10.1016/j. worlddev.2016.11.011

[27] Harianti, A., Malinda, M., Tjandra, M., \& Kambuno, D. (2021). Descriptive Analysis of Financial Literacy SMEs in Bandung. International Journal of Trade, Economics and Finance, 12(1). https://doi.org/10.18178/ijtef. 2021.12.1.686

[28] Harnoko, A. D., \& Herianingrum, S. (2020). Analisis Teori Perilaku Yang Direncanakan Terhadap Niat Warga Surabaya Untuk Kredit Pemilikan Rumah Syariah Di De Rayyan Developer Property. Jurnal Ekonomi Syariah Teori Dan Terapan, 7(8), 1527. https://doi.org/ 10.20473/vol7iss20208pp1527-1537

[29] Herdjiono, I., \& Damanik, L. A. (2016). Pengaruh Financial Attitude,Financial Knowledge, Parental Income Terhadap Financial Management Behavior. Jurnal Manajemen Teori 
Dan Terapan | Journal of Theory and Applied Management, 9(3), 226-241. https://doi.org/ 10.20473/jmtt.v9i3.3077

[30] Hill, R. J., Fishbein, M., \& Ajzen, I. (1977). Belief, Attitude, Intention and Behavior: An Introduction to Theory and Research. Contemporary Sociology, 6(2), 244. https://doi.org/ $10.2307 / 2065853$

[31] HIRA, T. K. (1997). Financial attitudes, beliefs and behaviours: differences by age. Journal of Consumer Studies and Home Economics, 21(3), 271-290. https://doi.org/10.1111/j.14706431.1997.tb00288.x

[32] Humaira, I., \& Sagoro, E. M. (2018). Pengaruh Pengetahuan Keuangan, Sikap Keuangan, Dan Kepribadian Terhadap Perilaku Manajemen Keuangan Pada Pelaku Umkm Sentra Kerajinan Batik Kabupaten Bantul. Nominal, Barometer Riset Akuntansi Dan Manajemen, 7(1). https://doi.org/10.21831/nominal.v7i1. 19363

[33] Janor, H., Yakob, R., Hashim, N. A., Aniza, C., \& Wel, C. (2016). Financial literacy and investment decisions in Malaysia and United Kingdom: A comparative analysis. Geografia: Malaysian Journal of Society and Space, 12(2), 106-118.

[34] Jawaheer, B. M., \& Manual, V. (2016). Gender Differences in Investment Decision Making Among the Working Class of Mauritius. Imperial Journal of Interdisciplinary Research, 2(9), 2454-1362. http:// www.onlinejournal.in

[35] Khoirunnisaa, J., \& Johan, I. R. (2020). The Effects of Financial Literacy and Self-Control towards Financial Behavior among High School Students in Bogor. Journal of Consumer Sciences, 5(2), 73-86. https://doi.org/10. 29244/jcs.5.2.73-86

[36] Kiki, P. E. (2013). Analisis Perkembangan Penyaluran Kredit Cepat Aman (KCA) untuk Meningkatkan Pendapatan PT. Pegadaian (Persero) Cabang Bandung Pasar Atas Tahun 2007-2014. 53(9), 1689-1699.

[37] Kumar, S., Watung, C., Eunike, J., \& Liunata, L. (2017). The Influence of Literacy towards Financial Behavior and Its Implication on Financial Decision: A Survey of President University Student in Cikarang-Bekasi. FIRM: Journal of Management Studies, 2(1), 14-23.

[38] Lie, R. L., \& Wiagustini, N. L. P. (2020). The Effect of Financial Literacy And Sociodemographic Factors on Millennial's Investment Decision-Making Behavior. International Journal of Economics and Management Studies, 7(7), 132-139. https://doi.org/10.14445/239391 25/ijems-v7i7p116
[39] Lown, J. M. (2011). 2011 oustanding AFCPE® Conference paper: Development and validation of a Financial Self-Efficacy Scale. Journal of Financial Counseling and Planning, 22(2), 54-63.

[40] Lown, J. M., Kim, J., Gutter, M. S., \& Hunt, A. T. (2015). Self-efficacy and Savings Among Middle and Low Income Households. Journal of Family and Economic Issues, 36(4), 491-502. https://doi.org/ 10.1007/s10834-014-9419-y

[41] Marlinah, L. (2020). Peluang dan Tantangan UMKM dalam Upaya Memperkuat Perekonomian Nasional Tahun 2020 Ditengah Pandemi Covid 19. Jurnal Ekonomi, 22(2), 118-124.

[42] Mochammad Rizaldy Insan Baihaqqy, \& Sugiyanto. (2020). Investment Decisions Of Investors Based On Generation Groups. Coopetition: Jurnal Ilmiah Manajemen, 11(3), 189-196. https://doi.org/10.32670/coopetition. v11i3.136

[43] Montford, W., \& Goldsmith, R. E. (2016). How gender and financial self-efficacy influence investment risk taking. International Journal of Consumer Studies, 40(1), 101-106. https://doi. org/10.1111/ijcs.12219

[44] Myšková, R., \& Doupalová, V. (2015). Approach to Risk Management Decision-Making in the Small Business. Procedia Economics and Finance, 34(15), 329-336. https://doi.org/10. 1016/s2212-5671(15)01637-8

[45] Ngui, G. K., \& Lay, Y. F. (2020). The effect of emotional intelligence, self-efficacy, subjective well-being and resilience on student teachers' perceived practicum stress: A Malaysian case study. European Journal of Educational Research, 9(1), 277-291. https://doi.org/10.12973/ eu-jer.9.1.277

[46] Niazi, M. K. S., \& Malik, Q. A. (2019). Financial attitude and investment decision makingmoderating role of financial literacy. NUML International Journal of Business \& Management, 14(1), 102-115. https://www.numl.edu. pk/journals/subjects/1564377799Article-8.pdf

[47] Noman, S., Bashir, T., \& Javed, S. (2020). Taking charge of your life: Locus of control, selfefficacy and saving behavior. International Journal of Advanced Science and Technology, 29(6 Special Issue), 569-587.

[48] Noor, N., Batool, I., \& Arshad, H. M. (2020). Financial literacy, financial self-efficacy and financial account ownership behavior in Pakistan. Cogent Economics and Finance, 8(1). https://doi.org/10.1080/23322039. 2020.1806479

[49] Panos, G. A., \& Wilson, J. O. S. (2020). Financial literacy and responsible finance in the FinTech era: capabilities and challenges. 
European Journal of Finance, 26(4-5), 297301. https://doi.org/10.1080/1351847X.2020. 1717569

[50] Pradiningtyas, T. E., \& Lukiastuti, F. (2019). Pengaruh Pengetahuan Keuangan dan Sikap Keuangan terhadap Locus of Control dan Perilaku Pengelolaan Keuangan Mahasiswa Ekonomi. Jurnal Minds: Manajemen Ide Dan Inspirasi, 6(1), 96. https://doi.org/10.24252/ minds.v6i1.9274

[51] Pumptow, M., \& Brahm, T. (2020). Students' Digital Media Self-Efficacy and Its Importance for Higher Education Institutions: Development and Validation of a Survey Instrument. Technology, Knowledge and Learning, 0123456789. https://doi.org/10.1007/s10758020-09463-5

[52] Putri, M. H., \& Pamungkas, A. S. (2019). Pengaruh Financial Knowledge, Locus of Control dan Financial Self Efficacy Terhadap Financial Behavior. Jurnal Manajerial Dan Kewirausahaan, I(4), 890-889.

[53] Qamar, M. A. J., Khemta, M. A. N., \& Jamil, H. (2016). How Knowledge and Financial SelfEfficacy Moderate the Relationship between Money Attitudes and Personal Financial Management Behavior. European Online Journal of Natural and Social Sciences, 5(2), 296-308. https://core.ac.uk/download/pdf/ 230044727. pdf

[54] Rasheed, R., \& Siddiqui, S. H. (2019). Attitude for inclusive finance: influence of ownermanagers' and firms' characteristics on SMEs financial decision making. Journal of Economic and Administrative Sciences, 35(3), 158171. https://doi.org/10.1108/jeas-05-2018-0057

[55] Rosli Mahmood, Mahmood, R., Aarakit, S. M., Alarape, A. A., Al-swidi, A. K., Al-Hosam, A., Aminu, I. M., Shariff, M. N. M., Zhongfeng Su, En Xie, and Y. L., Ahmed, I., Ali, G., Ramzan, M., Andersén, J., Anderson, B. S., Eshima, Y., Arbaugh, J., Larry, W., Camp, S., Arief, M., ... Me, N. (2013). Entrepreneurial orientation and business performance of women-owned small and medium enterprises in Malaysia: Competitive advantage as a mediator. International
Journal of Business and Social Science, 4(1), 82-90. https://doi.org/10.1177/0266242612455 034

[56] Sagita, A. A., Indrawati, L. R. I., \& Jalunggono, G. (2019). Analisis Faktor-Faktor Yang Mempengaruhi Penyaluran KMK terhadap UMKM pada Bank Umum di Indonesia Tahun 2014-2018. Dinamic: Directory Journal of Economic, 1(4), 360-370.

[57] Sugiyono. (2008). Metode penelitian pendidikan: (pendekatan kuantitatif, kualitatif dan $R$ $\& D)$. Alfabeta.

[58] Tan, C. S., Ooi, H. Y., \& Goh, Y. N. (2017). A moral extension of the theory of planned behavior to predict consumers' purchase intention for energy-efficient household appliances in Malaysia. Energy Policy, 107 (January 2016), 459-471. https://doi.org/10.1016/j.enpol. 2017.05.027

[59] Vargo Christian L. Tobing. (2020). Analisis Suku Bunga Kredit Dan Jaminan Kredit Terhadap Keputusan Pengambilan Kredit Pada Perusahaan Pembiayaan Di Kota Batam. Jurnal Akuntansi Dan Investasi, 3(2), 139-150. http://ejournal.unira.ac.id/index. php/ jurnal_aktiva/article/view/925

[60] Widiyati, S., Wijayanto, E., \& Prihartiningsih, P. (2018). Financial Literacy Model at Micro Small Medium Entreprise (SMEs). MIMBAR: Jurnal Sosial Dan Pembangunan, 34(2), 255264. https://doi.org/10.29313/mimbar.v34i2. 2914

[61] Xiao, J. J., Chatterjee, S., \& Kim, J. (2014). Factors associated with financial independence of young adults. International Journal of Consumer Studies, 38(4), 394-403. https://doi.org/ 10.1111/ijcs. 12106

[62] Yogasnumurti, R. R., Sadalia, I., \& Irawati, N. (2020). The effect of financial attitude and financial knowledge on personal financial management of university students moderated by gender. International Journal of Research and Review, 7(2), 219-229.

[63] Yokoyama, S. (2019). Academic self-efficacy and academic performance in Online Learning: A mini review. Frontiers in Psychology, 9(JAN), 1-4. https://doi.org/10.3389/fpsyg.2018.02794 